Canadian University Music Review

Revue de musique des universités canadiennes

\title{
George A. Proctor. Canadian Music of the Twentieth Century. Toronto: University of Toronto Press, 1980, xxvi, 297 pp.
}

\section{Bruce W. Pennycook}

Numéro 2, 1981

URI : https://id.erudit.org/iderudit/1013757ar

DOI : https://doi.org/10.7202/1013757ar

Aller au sommaire du numéro

Éditeur(s)

Canadian University Music Society / Société de musique des universités

canadiennes

\section{ISSN}

0710-0353 (imprimé)

2291-2436 (numérique)

Découvrir la revue

Citer ce compte rendu

Pennycook, B. W. (1981). Compte rendu de [George A. Proctor. Canadian Music of the Twentieth Century. Toronto: University of Toronto Press, 1980, xxvi, 297 pp.] Canadian University Music Review / Revue de musique des universités canadiennes, (2), 233-236. https://doi.org/10.7202/1013757ar

All Rights Reserved (C Canadian University Music Society / Société de musique des universités canadiennes, 1981
Ce document est protégé par la loi sur le droit d'auteur. L'utilisation des services d'Érudit (y compris la reproduction) est assujettie à sa politique d'utilisation que vous pouvez consulter en ligne.

https://apropos.erudit.org/fr/usagers/politique-dutilisation/ 
is quite likely that names which are not to be found in other standard sources on Canadian music may appear here and so the work will, no doubt, serve a useful function for researchers, communications people, and musicians.

Beverly Cavanagh

LARRY C. LEWIS, ed. Union List of Music Periodicals in Canadian Libraries, 2nd ed. Ottawa: Canadian Association of Music Libraries, 1981, $293 \mathrm{pp}$.

This reference work represents not only an updating but a considerable expansion of the first edition of 1964 and supplement (1967). The current list of 1,783 titles as reported by the forty-five participating libraries demonstrates the expansion of music research and education in every province in Canada during the past fifteen years. As well as noting library holdings for each periodical, information about changes in title, publication or numbering irregularities are indicated. Both contemporary and historical yearbooks/newsletters/ journals are included.

The computerization of this list should allow for more frequent revisions in the future. The 1981 edition is approximately three years out of date according to the acquisitions department at the reviewer's university. While this is not an unacceptable compilation-to-publication gap, one would hope for an even smaller margin given the present state of word-processing technology.

One serious omission from the list, preceding p. 1, of participating libraries is the University of Toronto, Faculty of Music Library. The holdings of this large and important collection are indexed; hence the reader might puzzle over the frequently-cited abbreviation for this library, OTUFM.

In general, however, this is a carefully compiled addition to our reference shelves.

Beverly Cavanagh

GEORGE A. PROCTOR. Canadian Music of the Twentieth Century. Toronto: University of Toronto Press, 1980, xxvi, 297 pp.

George Proctor has recognized the long-standing need for a guide to the rapidly expanding body of Canadian contemporary music. Unlike literature, poetry and, to some extent, painting and sculpture, Canadian composition has not attained a strong public profile despite the 
laudable efforts of the Canadian Music Centre, The Canada Council for the Arts, and the Canadian Broadcasting Corporation to promote and disseminate Canadian works. Although performing artists such as Glenn Gould, Maureen Forrester, and Teresa Stratas enjoy considerable national and international visibility, Canadian composers, the creators of the art, rarely receive broad-spectrum media coverage.

There are several rather complex reasons why Healey Willan, John Weinzweig, and R. Murray Schafer have not emerged as prominent contemporary cultural figures, like Tom Thomson, Leonard Cohen, or Harold Towne. Perhaps the most significant factor is the relative inaccessibility of contemporary musical idioms compared to other art forms, and it is likely that no amount of subsidized promotion will temper this problem. However, Proctor has addressed two correctable problems. He states that his principle aims are first, "to bridge the sizeable gap which at present exists between the producer and the consumer of Canadian music" (p. ix), and second, "to bring together the sources of scores and recordings" (p. $x$ ). The author has blended these two goals into a form which presents a carefully selected chronology of works organized by genre and performance medium. In Proctor's words, the text provides, "an introduction to the music itself, the varied products of musical creation by many individual composers" (p. ix).

The seven chapters of the book divide more or less by decade the substantial growth since 1900 of creative output, musical activity, and the establishment of the major musical institutions and ensembles across the nation. Proctor has attempted to amplify the major tendencies of each period through stylistic labels. Although some readers may object to the general attribution of "Neoclassicism" to the 1950s and "New Romanticism" to the 1960s, the terms do tend to reflect the musical objectives of a majority of the works described and/or listed in the selective list of works, scores, and recordings which follows each chapter. For example, in Chapter 2, "1921-1940: Early Nationalism," a significant number of works are based on nationalistic ideas, indigenous folk materials, or regionally popular musical styles reflecting the general trend in the literary and visual arts toward Canadian topics. Unfortunately, as Proctor points out, many of these works were shallow and inconsequential. Canadian composers were still more comfortable with the rhetorical romanticism of the nineteenth century or the imperial styles of Parry and Elgar.

From about 1940 to the present, Canadian composition began to exhibit aspects of the techniques of Schoenberg and Stravinsky, whose works represented the principal stylistic camps of modern composition. Proctor demonstrates that the recent immigrant musicians and young Canadian composers returning from studies in Europe and the United States (Papineau-Couture, Pentland, Weinzweig, Anhalt, etc.) enthusi- 
astically promulgated in their works unique and compelling versions of the new language.

The establishment of the Canadian League of Composers in 1951 and the vigorous endeavors of the CBC did much to nurture interest by the press and the music-going public. The author outlines the rise of these and other important institutions, orchestral bodies, and government agencies which, over the last three decades, have contributed immeasurably to the growth and dissemination of Canadian composition. The general flourishing of compositional activity from after World War II to the present is clearly established by Proctor both in the expanded number of entries and the depth of critical appraisal.

The inclusion of Chapter 6, "1967: Centennial Celebrations," significantly enhances the book. A majority of the Centennial pieces (of which 130 listed by the Canadian Music Centre are summarized by genre) were commissioned by government agencies. Proctor states: "For the first time Canadian composers had a relatively high profile, and a few even earned a significant proportion of their income through the various commissions they received" (p. 150). Although several works have become repertoire, at least within this country, the author points out that many have never received subsequent performances and a few, including Anhalt's Symphony of Modules, still await their premieres. The diversity of musical forces and styles illustrated in this chapter demonstrates the remarkable range of compositional activity for the nation's Centennial. There can be little doubt that Harry Somer's trilingual opera, Louis Riel, John Weinzweig's Harp Concerto, and Bruce Mather's Madrigals will enjoy a permanent place in the repertoire.

Proctor expresses concern about "the degree to which dependence on support from governmental and other granting agencies limits the freedom of the composer" (p. 175). I sympathize with this but am also concerned with the low incidence of repeat performances of commissioned works. The ever-increasing solo works and pieces for such major ensembles as the Canadian Brass can only be beneficial. However, the prevailing tendency toward extremely difficult and complex musical styles, as described in the text, too often results in music with a very short life span.

In keeping with the aim toward a fairly broad readership, Proctor has kept the language relatively simple and has minimized biographical accounts which can readily be found in other texts (e.g., Beckwith and MacMillan, Contemporary Canadian Composers; the Appendix, moreover, includes a selective bibliography drawn from Proctor's previous research and publications). However, the imposed brevity too frequently results in glossing and an annoying tendency to describe stylistic traits or compositional mechanisms in simplistic terms. To illustrate, in Chapter 3, Proctor states that the Fanfare and Passacaglia by Violet Archer "consists of a six-measure chromatic phrase which is well- 
balanced in contour, uses intervals of the minor third, perfect fourth, and perfect fifth, and makes a dramatic leap of a minor seventh at the end of the phrase" (p. 42). Surely, a reader able to derive meaning from this description would gain a much clearer picture from a score excerpt. Furthermore, the excerpts frequently do not follow the text sequentially and in some cases have no accompanying elaboration at all.

Despite these minor objections, this book fills a serious gap in the body of literature on Canadian music and composition. It is the sort of text that can be used for locating previously elusive source materials, teaching introductory courses in Canadian music, or general reading. Perhaps more importantly, it serves as a systematic guide to the significant artistic activity in this country over the last eight decades which, for the most part, remains unknown to the international music community.*

Bruce W. Pennycook

*Reprinted by permission from Queen's Quarterly, LXXXVIII/4 (Winter 1981), 781-83.

TERENCE BAILEY: The Processions of Sarum and the Western Church. (Studies and Texts, No. 21.) Toronto: Pontifical Institute of Mediaeval Studies, 1971, xv. 208 pp.

Primary research into medieval music often results in one of several distinct kinds of publication: manuscript inventories; histories of people, places, and/or rites; analytical discourses; genre studies; and critical editions. All are useful, but the indulgent wallowing in detail, deliberate myopia, or the rigor mortis of apparatus criticus, that is, arid pedantry, can mercilessly suffocate the reader. Such is not the case with Terence Bailey's book. One of the refreshing qualities is its wealth of interrelationship; it describes a microcosm replete with its own interdependencies and demonstrates how this fits the macrocosm of Western liturgical practice, yet not at the expense of minutiae.

Bailey's monograph "proposes to describe and study the ceremonies and chants of the processions of the Western Church as a whole" (p.ix) through a detailed examination of practices at Salisbury. In spite of the balkanization characteristic of Europe in the Middle Ages, Sarum chant constitutes a reasonable focal point for such a study because of its pre-eminent position, the demonstrable approbation it was accorded in Rome, and its relatively widespread adoption outside its home cathedral. Not only does its corpus include the sole fully-rubricated medieval Processional, but also a full complement of related service books. In tandem, these allow an examination of the liturgy and music (an integral part of the former) which would hardly be possible to duplicate in a study based on any other extant corpus of chant. 